\title{
CMENTARZ WOJENNY PRZY UL. BIAŁEJ W LUBLINIE - PROBLEMATYKA OCHRONY ZABYTKU
}

\author{
Halina Landecka \\ Wydział Budownictwa i Architektury, Katedra Architektury, Urbanistyki i Planowania Przestrzennego, \\ Politechnika Lubelska \\ Faculty of Civil Engineering and Architecture, \\ Department of Architecture, Urban and Spatial Planning, LublinUniversity of Technology \\ e-mail:h.landecka@pollub.pl
}

\begin{abstract}
Streszczenie. Cmentarz wojenny przy ul. Białej w Lublinie położony w zespole cmentarzy: komunalnego, katolickiego, ewangelickiego i prawosławnego został założony w związku z koniecznością zapewnienia pochówków żołnierzy poległych podczas I wojny światowej. Projekt cmentarza o regularnym układzie grobów i alej, z kaplicą cmentarną na osi powstał w 1917 w austriackiej pracowni architektonicznej. W kolejnych latach cmentarz nadal zapełniał się grobami żołnierzy, ale także pojawiały się groby członków rodzin wojskowych, a w latach władzy ludowej - zasłużonych działaczy państwowych.

Obok prostych grobów ziemnych z krzyżami pojawiły się murowane pomniki i współczesne grobowce. Regularny układ został zakłócony, nie użytkowana od lat 70. kaplica popadła w ruinę, cmentarz przejęła pod zarząd gmina Lublin. Prace restauratorskie zostały podjęte w latach 2007-2009 z inicjatywy mec. Jerzego Kiełbowicza. Przeprowadzono kapitalny remont kaplicy, konserwację polichromii zdobiących wnętrze oraz detali architektonicznych.

Kwatery wojskowe, główne aleje, zieleń zostały w części uporządkowane. Konieczne jest opracowanie planu rewaloryzacji całego cmentarza wojennego w celu uczytelnienia jego historycznego układu i zabytkowych wartości.
\end{abstract}

Słowa kluczowe: cmentarz wojenny, ochrona zabytków, restauracja

Cmentarz wojenny przy ul. Białej w Lublinie znajduje się w obrębie lubelskiego zespołu cmentarzy położonych między ul. Lipową, Wiercińskiego, Głęboką, Raabego i Obrońców Pokoju. Zespół ten obejmujący cmentarze: komunalny, rzymsko-katolicki, ewangelicki, prawosławny, został wpisany do rejestru zabytków województwa lubelskiego 29 stycznia $1985 \mathrm{r}$. pod $\mathrm{nr} \mathrm{A} / 889$. Cmentarz wojenny funkcjonuje dziś pod nazwą cmentarza wojskowego i włączony jest w obręb cmentarza komunalnego zarządzanego przez gminę - miasto Lublin.

Historia cmentarza wojennego sięga roku 1914. Jego założenie wiązało się z koniecznością zapewnienia miejsca pochówku żołnierzy poległych w wojnie armii Austro-Węgier z bolszewikami. W wyniku działań wojennych prowadzonych w latach 1914-16 na terenie Lubelszczyzny wielu żołnierzy zginęło bezpośrednio w boju, część z nich w wyniku odniesionych ran zmarła w szpitalach, m.in. w szpitalu św. Krzyża (obecnie teren Katolickiego Uniwersytetu Lubelskiego) gdzie funkcjonował rosyjski szpital wojskowy ${ }^{1}$. Na realizację cmentarza wykorzystane zostały dwie działki: jedna nabyta przez władze austro-węgierskie od Towarzystwa Opieki nad Cmentarzami Rzymsko-Katolickimi i druga skonfiskowana od gminy rosyjskiej ${ }^{2}$. Plan zakładał regularny układ alejek i kwater. Kompozycja oparta została na dwóch osiach - głównej alei dojazdowej z bramą wjazdową od strony północnej i alei prostopadłej do niej, wyznaczającej oś symetrii kaplicy. Decyzją austriackich władz wojskowych, w pracowni Technische Abteilung K.U.K Kreiskomandos in Lublin, opracowany został

1 M.Dąbrowski, L.Popik, Cmentarz wojenny przy ul. Białej w Lublinie. Opracowanie historyczno-przestrzenne, Lublin 1999, mps w zbiorach WKZ Lublin, s. 3-15.

2 Cmentarze: „Pod Lipkami” (założony w 1794 roku) oraz prawosławny (założony w 1831 r.) już wówczas funkcjonowały. 
szczegółowy projekt budowy kaplicy³. Dokumentacja zawierająca rysunki budowlane (rzuty, przekroje, elewacje) opatrzona jest stemplem pracowni, datą 11.XI.16 i podpisem K. Jedlicki. Materiały archiwalne zachowały się w zbiorach Archiwum Państwowego w Lublinie.

Kaplica wzniesiona została w roku 1917. Budynek ma plan krzyża greckiego z półkolistą absydą od strony zachodniej i dwukolumnowym portykiem zwieńczonym łukiem od wschodu. Pole w półłuczu wypełnia przeszklenie stanowiące jednocześnie nadświetle drzwi. Całość dekoracji dopełnia wałek w formie wieńca ze stylizowanych liści dębu, zamknięty zwornikiem z płaskorzeźbą twarzy Chrystusa w koronie cierniowej. Konstrukcja ścian jest ceglana, wnętrze absydy sklepione, nawa przekryta stropem płaskim, dach czterospadowy (namiotowy) pokryty blachą płaską, z sygnaturką na szczycie. Przyziemie budynku obiega niski cokół, a górne partie gzyms kordonowy. Wnętrze kaplicy było pokryte dekoracją malarską i sztukateryjną dostosowaną do charakteru i przeznaczenia obiektu ${ }^{4}$.

Na nowy cmentarz wojenny przeniesione zostały szczątki żołnierzy pochowanych dotychczas na części rzymsko-katolickiej. Utworzono także groby polskich legionistów i żołnierzy włoskich - w 1917 roku odnotowano w archiwach 15 grobów masowych. W latach 1918-19 sprowadzono kolejne ciała - ok. 400 żołnierzy poległych w walkach na wschodzie, w Galicji i na Podlasiu. Żołnierzy chowano w mogiłach ziemnych oznaczonych krzyżami opatrzonymi nazwiskiem i datą (o ile pozwalała na to identyfikacja) lub w mogiłach zbiorowych - bezimiennych.

W 1922 roku cmentarz został przejęty przez Dyrekcję Robót Publicznych - Oddział 5 Grobownictwa Wojennego przy urzędzie wojewódzkim. Od tego czasu nowy zarządca dopuszczał wprowadzanie grobów żołnierzy zmarłych już w okresie powojennym, a także osób cywilnych $\mathrm{z}$ rodzin wojskowych. Tym samym cmentarz z wojennego stał się cmentarzem garnizonowym - szerzej dostępnym. ${ }^{5}$ W roku 1928 uporządkowane zostały mogiły 1900 żołnierzy, wykonano remont kaplicy i domku dozorcy.

W 1934 z inicjatywy Związku Legionów Polskich w Lublinie ufundowany został pomnik pamięci legionistów pierwszej, drugiej i trzeciej brygady, według projektu architekta Tadeusza Witkowskiego. Obelisk umieszczono na kwaterze z grobami legionistów poległych w 1915-16 roku oraz w latach 30. Kompozycja z surowych bloków betonowych zwieńczona jest metalowym zniczem, elewację frontową zdobi orzeł z brązu i napis fundacyjny, na elewacji bocznej umieszczona została granitowa tablica z nazwiskami legionistów.

Po II wojnie światowej nastąpiły dalsze zmiany w zagospodarowaniu terenu cmentarza. Utworzone zostały nowe mogiły zbiorowe partyzantów Armii Krajowej i poległych na Lubelszczyźnie żołnierzy Wojska Polskiego. Od lat 50. XX w. cmentarz wojskowy zarządzany przez Ministerstwo Obrony Narodowej staje się także miejscem pochówku komunistycznych działaczy, funkcjonariuszy Komitetu Bezpieczeństwa Wewnętrznego, Służby Bezpieczeństwa, milicji, osób zasłużonych dla władzy ludowej. Część mogił ulega stopniowym przekształceniom w groby rodzinne. Przypadkowa lokalizacja mogit, wydzielanie z kwater wojskowych nowych miejsc dla pochówków cywilnych powodowało postępujące zacieranie i zniekształcanie starannie zakomponowanego, regularnego układu cmentarza wojennego zaprojektowanego przez władze austriackie w 1916 roku. Groby współczesne, ozdobione typowymi formami pomników granitowych, lastrykowych, otoczone opaskami z bruku, uzupełnione rabatkami i różnej konstrukcji „ławeczkami” trwale zmieniły charakter cmentarza. Mogiły i kwatery wojenne z czasem przestały dominować w jego przestrzeni. Od roku 1965 cmentarz znalazł się pod

3 Op.cit., s. 15 i 20.

4 R. Róg, Sprawozdanie z przeprowadzonych badań sondażowych, II etap-ściany, sztukaterie, opr. w zbiorach archiwum WKZ w Lublinie.

5 Op. cit. s. $16-18$ 
zarządem służb miejskich i od tego okresu do dziś funkcjonuje wraz z przyległym od wschodu obszarem jako otwarty cmentarz komunalny.

W 1990 roku powstała inicjatywa budowy pomnika ofiar Katynia. ${ }^{6}$ Symboliczna kamienna Mogiła Katyńska, według projektu Lucjana Ociasa i Marka Piątkowskiego, powstała z wykorzystaniem muru cmentarnego i jego bramek. Wmurowano w nią urny z ziemią z Katynia, Ostaszkowa i Miednoje, a na 15 tablicach umieszczono 249 nazwisk oficerów i funkcjonariuszy, którzy pochodzili z Lubelszczyzny i zostali zamordowani w tych obozach. Uroczystości z udziałem ocalałych jeńców odbyły się 30 maja 1993 roku.

Kaplica cmentarna od lat 80 . XX w. praktycznie nie była użytkowana i ulegała stopniowej destrukcji. Z inicjatywy mecenasa Jerzego Kiełbowicza - prezesa powstałego Regionalnego Stowarzyszenia Zwolenników Kremacji w Lublinie - w 2007 r. podjęto działania mające na celu wyremontowanie zaniedbanego obiektu. Na podstawie zawartego porozumienia $\mathrm{z}$ władzami miasta w pierwszym etapie wykonano ekspertyzę z oceną stanu konstrukcyjnego, która posłużyła do opracowania projektu budowlanego remontu kaplicy. Autorami opracowania byli mgr inż. arch. Stanisław Pilut (branża architektoniczna), mgr inż. Teresa Tatar (branża konstrukcyjna). Wyprzedzająco wykonane zostały badania konserwatorskie wnętrza, które potwierdziły występowanie dekoracji malarskiej i detalu sztukatorskiego. Z wniosków z badań (prowadzonych przez dyplomowanego konserwatora dzieła sztuki Rolanda Roga) wynika, że odsłonięta polichromia w absydzie pochodzi prawdopodobnie z 1929 roku, a zastosowane motywy dekoracyjne nawiązują do ornamentów młodopolskich chętnie stosowanych w okresie międzywojennym.

Prace remontowe objęly kompleksowy zakres robót budowlany przy fundamentach, ścianach, konstrukcji stropu i więźby dachowej. Wymieniono zniszczone pokrycie dachu, tynki, odnowiono elewacje, dokonano reperacji schodów, uporządkowano zieleń wokół kaplicy i wprowadzono nową nawierzchnię z cegły klinkierowej na głównej alejce dojazdowej. W ramach specjalistycznych prac konserwatorskich oczyszczono z wtórnych nawarstwień malowidła w absydzie, wzmocniono strukturalnie i uzupełniono sztukaterie oraz oryginalne wyprawy tynkowe. Kolorystykę wnętrza oparto na wynikach badań. Konserwacji poddana została także przeszklona stolarka i detale drzwi wejściowych oraz sztukateryjna dekoracja arkadowego portyku. ${ }^{7}$ Wyposażenie wnętrza zaprojektowane zostało w nawiązaniu do charakteru obiektu, przy założeniu, że kaplica będzie pełnić rolę ekumenicznego miejsca celebry pogrzebowej. Nowy stół ołtarzowy, katafalk i podstawa pod urnę, siedziska, strefa przygotowania celebry, organy zostały starannie wkomponowane w odnowioną przestrzeń i dostosowane do różnych form ceremonii. W 2009 roku realizacja została wyróżniona nagrodą „Laur Konserwatorski” w konkursie pod patronatem Generalnego Konserwatora Zabytków, Wojewody Lubelskiego i Marszałka Województwa organizowanym przez Wojewódzkiego Konserwatora Zabytków w Lublinie.

Z inicjatywy Stowarzyszenia Zwolenników Kremacji w Lublinie podjęte zostały także prace porządkowe $\mathrm{w}$ obrębie cmentarza, roboty remontowe przy północnej części muru ogrodzeniowego, przy nawierzchniach alejek. W najstarszych, austriackich kwaterach wojennych wymienione zostały obrzeża i krzyże, założono nowe trawniki.

W związku ze statutowym celem Stowarzyszenia, w porozumieniu z gminą Lublin, przy alei wschodniej cmentarza zlokalizowano kolumbarium. Dodatkowo na miejsca urnowe wykorzystane zostały także nisze w bramkach wyremontowanego ogrodzenia od strony północnej.

6 Z inicjatywą wystąpił Tadeusz Ruciński, a ideę tę podjął Społeczny Komitet Ochrony Zabytków Cmentarnych przy wsparciu Lubelskiej Rodziny Katyńskiej dane wg Karty Miejsca Pamięci Narodowej aut. K. Gerłowskiej, 1996 r. - w zbiorach archiwum WKZ w Lublinie.

7 Prace prowadził konserwator dzieł sztuki Roland Róg, projekt aranżacji wnętrz wykonała artysta plastyk Halina Kuśnierz. 
Ze względu na szczególne wartości historyczne i przestrzenne niemal stuletni zabytkowy cmentarz wojenny (potem wojskowy, a dziś komunalny) wymaga zapewnienia warunków gwarantujących zachowanie jego istotnych cech. Podstawą powinien być projekt rewaloryzacji i starannie opracowany regulamin cmentarza określający warunki i zakresy dopuszczalnych działań w jego obrębie. W 2013 roku zarząd wspomnianego stowarzyszenia podjął wstępne przygotowania do opracowania projektu rewaloryzacji cmentarza i realizacji części prac remontowych i konserwatorskich przed zbliżającą się w 2014 roku setną rocznicą wybuchu I wojny światowej i założenia cmentarza. W oparciu o wytyczne konserwatorskie obejmujące zalecenia dotyczące uczytelnienia kompozycji cmentarza, gospodarki drzewostanem, nawierzchni alej, prac konserwatorskich przy grobach, mogiłach i pomnikach, robót budowlanych przy budynkach i ogrodzeniu, prac porządkowych w obrębie cmentarza i w alei dojazdowej od ulicy Białej, miał powstać projekt docelowych rozwiązań.

Zamierzenie uzyskało pozytywną opinię działającego przy Wojewodzie Lubelskim Wojewódzkiego komitetu Ochrony Pamięci Walk i Męczeństwa, nie spotkało się jednak z uznaniem bezpośredniego zarządcy - Gminy Lublin. Opracowania całościowo obejmujące teren zabytkowego cmentarza do dzisiaj nie powstały.

Prace remontowo-konserwatorskie prowadzone są nadal wyłącznie w wybranych fragmentach założenia i w ograniczonym zakresie. Współczesne nazwanie cmentarza „komunalnym” nie może stanowić podstawy przekreślenia jego wartości historycznych sięgających początku XX wieku.. Cmentarz został założony w roku 1917 jako „wojskowy” (wojenny), znajduje się na nim kilkaset mogił żołnierzy armii polskich, austro-węgierskich, poległych zarówno w I jak i II wojnie światowej, odbywają się na nim ceremonie wojskowe - często z udziałem delegacji zagranicznych. Zabytek wciąż czeka na kompleksowe prace rewaloryzacyjne.

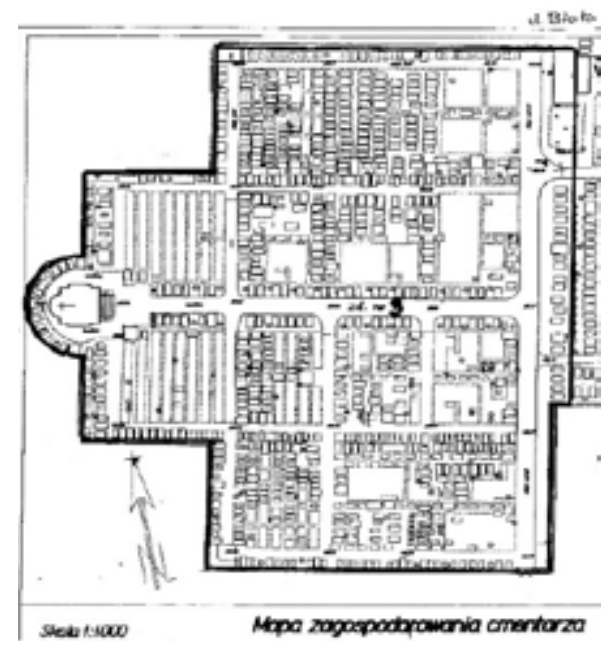

Ryc. 1. Schemat planu cmentarza wojennego przy ul. Białej w Lublinie Fig. 1. The scheme of war cemetery at Biala street in Lublin

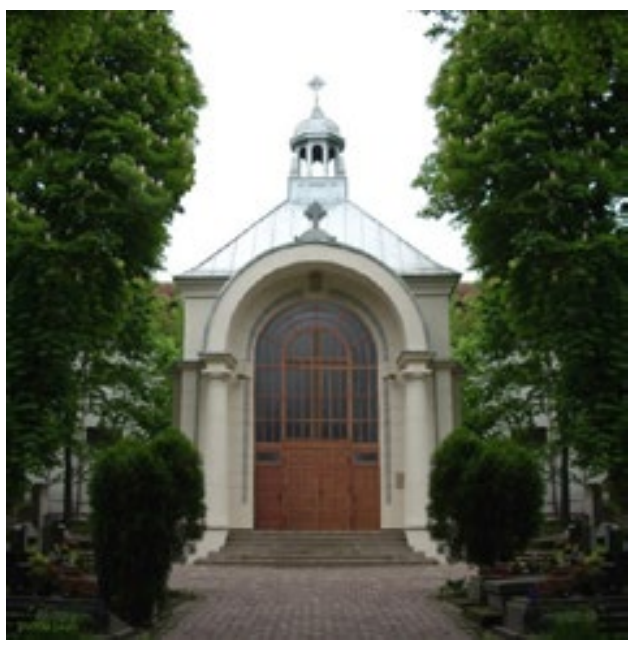

Ryc. 2. Kaplica cmentarna po pracach remontowych przeprowadzonych w roku 2007 fot. ze zbiorów WKZ w Lublinie

Fig 2. The cemetery chapel after restoration works in 2007, source: WKZ Lublin 


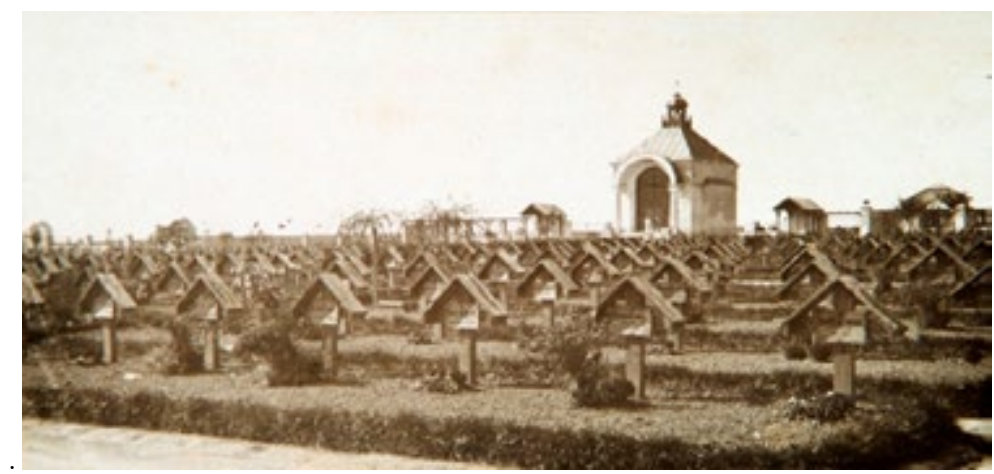

Ryc. 3. Fotografia aut. F. Lala z albumu „Valka 1914-1918”

Fig. 3. Phot. auth.. F. Lala from the album "Valka 1914-1918” gained by Lubelskie Museum

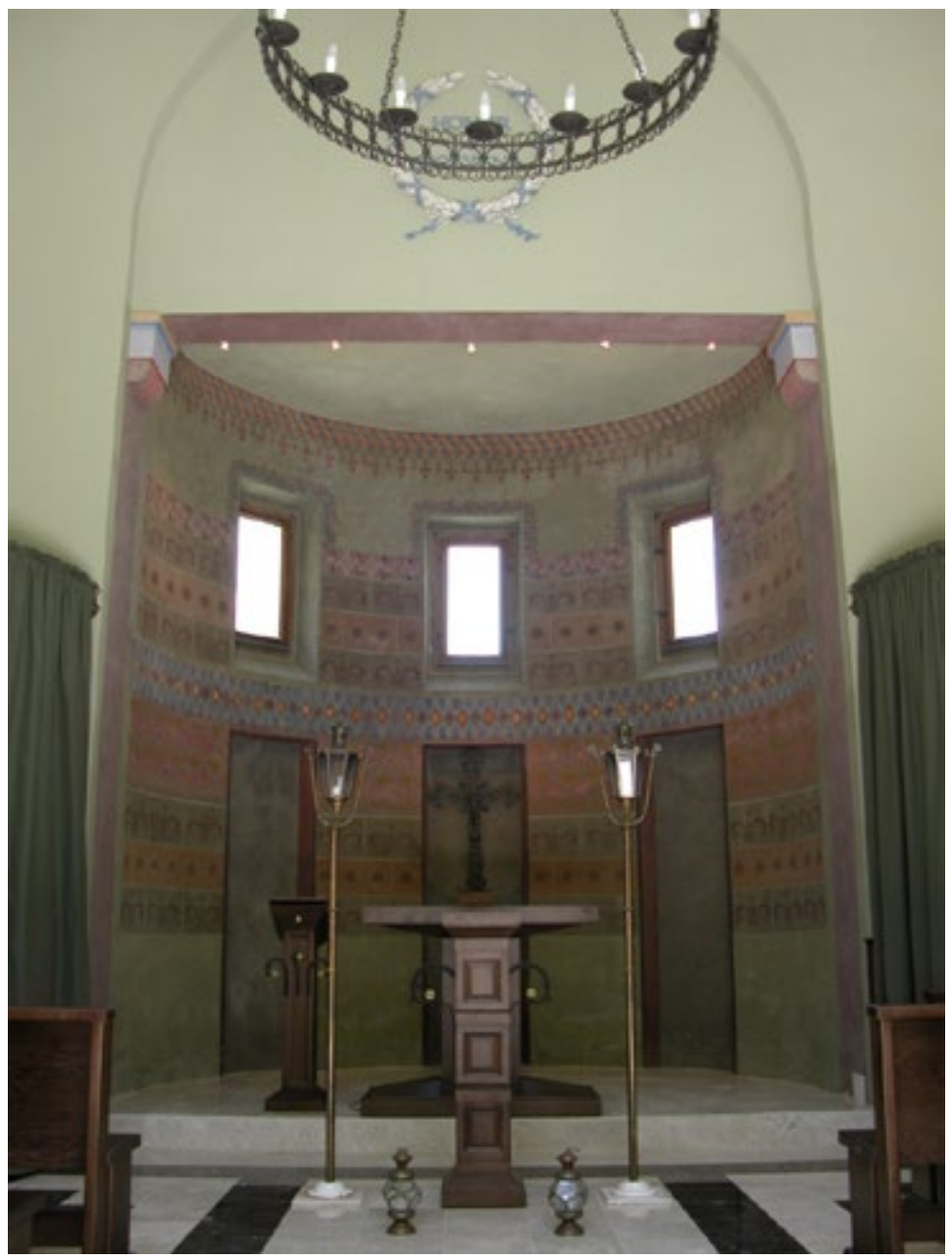

Ryc. 4. Dekoracja wnętrza kaplicy po pracach konserwatorskich - fot. ze zbiorów WKZ w Lubinie Fig. 4. Decoration of interior walls in cemetery chapel - after conservation 


\title{
PIŚMIENNICTWO
}

Dąbrowski M., Popik L.,1999. Cmentarz wojenny przy ul. Białej w Lublinie. Opracowanie historyczno-przestrzenne, mps w zbiorach WKZ Lublin, s.3-15

R.Róg, Sprawozdanie z przeprowadzonych badań sondażowych, II etap -ściany, sztukaterie, opr. w zbiorach archiwum WKZ w Lublinie.

\section{WAR CEMETERY AT BIAŁA STREET IN LUBLIN - MONUMENT PROTECTION ISSUES}

\begin{abstract}
The war cemetery on Biała Street in Lublin, together with Old Catholic, Orthodox and Evangelic cemeteries are listed as the important monuments in Lublin region. The war cemetery layout was done during the I World War and its design was prepared by Austrian architects in 1917 with typical characteristics for such places: regular form with chapel located on the main axe, perpendicular alley lines and cemetery sections, simplistic graves with crosses and soldiers' names.

During the following years cemetery became transformed to become the communal place with new tombs and monuments founded to commemorate great people, politics and notable families. New forms became dominant destroying old soldiers' graves and cemetery chapel and the original design get out of shape.

In 2007 Mr Jerzy Kiełbowicz - known lawyer from Lublin - started the initiative of renovating the part of old war cemetery. The chapel was fully repaired with all architectural details and interior decoration (polychromic wall painting) preserved, all of the oldest sections with soldier's graves were regulated.

War cemetery on Biała Street still awaits for a capital program of restoration as its historic and memory value ought to be protected and properly preserved.
\end{abstract}

Key words: war cemetery, monument protection, restoration 